\title{
Evaluasi kesesuaian standar ukuran vertikal slot breket ortodonti The evaluation of the standard validity of vertical orthodontic bracket slot size
}

\author{
${ }^{1}$ Parta L. Silitonga, ${ }^{2}$ Bergman Thahar, ${ }^{2}$ Endah Mardiati, ${ }^{2}$ Tono Hambali, ${ }^{2}$ Eky Soeria Soemantri \\ ${ }^{1}$ Laboratorium Kesehatan Gigi Mulut TNI AU \\ ${ }^{2}$ Bagian Ortodonti Fakultas Kedokteran Gigi Universitas Padjadjaran \\ Bandung, Indonesia
}

\begin{abstract}
On orthodontic treatment, accuracy of orthodontic brackets slot size is essential for maximum interaction between the wire and brackets, so as to distribute the optimal force for tooth movement. The purpose of this study was to determine the accuracy of orthodontic brackets slot size to 0.018 inch standard sizes that are available in the market. The sample was selected by using a random sampling system, which consists of 15 types of brackets of 8 bracket manufacturers with a total sample of 300 samples. Measurements performed on 4 sides of slot bracket, namely the outer and inner sides of the brackets slot, on mesial and distal sides, using a profile projector (Mitutoyo Type PJ250). The results were statistically tested using t-test one side. All brackets have a slot size significantly larger than the standard size. The average percentage of magnification ranged from $5.18-24.29 \%$. So, it was concluded that the size of the slot brackets available in the Indonesian market greater than their standard.
\end{abstract}

Keywords: orthodontic bracket, brackets slot size, accuracy of orthodontic bracket slot size

\begin{abstract}
ABSTRAK
Pada perawatan ortodonti, keakuratan ukuran slot breket ortodonti sangat penting untuk interaksi maksimal antara kawat dan breket, sehingga dapat menyalurkan gaya yang optimal untuk pergerakan gigi. Tujuan penelitian ini adalah untuk mengetahui keakuratan ukuran slot breket ortodonti terhadap ukuran standar 0,018 inci yang sudah tersedia di pasaran. Sampel dipilih dengan cara menggunakan sistem random sampling, yang terbagi atas 15 tipe breket dari 8 produsen breket dengan total sampel 300 sampel. Pengukuran slot breket dilakukan pada 4 sisi, yaitu pada sisi terluar dan terdalam slot breket, pada sisi mesial dan distal. Pengukuran dilakukan menggunakan alat profil proyektor (Mitutoyo Type PJ250). Hasil pengukuran diuji secara statistik dengan menggunakan uji-t satu pihak. Hasil penelitian menunjukkan seluruh sampel breket, secara signifikan memiliki ukuran slot breket yang lebih besar dari ukuran standar. Rata-rata persentase pembesaran berkisar antara 5,18-24,29\%. Disimpulkan bahwa ukuran slot breket yang ada di pasaran Indonesia memiliki ukuran yang lebih besar dari pada standarnya
\end{abstract}

Kata kunci: breket ortodonti, ukuran slot breket, keakuratan ukuran slot breket ortodonti

Koresponden: Parta L. Silitonga, Lakesgilut TNI AU, Jl. Punto Dewo No.1 Komplek Dirgantara II, Lanud Halim Perdana Kusuma, Jakarta Timur 13610, Indonesia.E-mail: lakesgilut@gmail.com

\section{PENDAHULUAN}

Perawatan ortodonti bertujuan memperbaiki kehidupan pasien dengan meningkatkan fungsi gigi, rahang serta estetik dentoskeletal, selain mengatasi kesulitan psikososial yang disebabkan oleh maloklusi gigi serta pencegahan gangguan fungsi dan otot-otot pengunyahan, dan fasial, sendi temporomandibula serta jaringan periodontal. ${ }^{1,2}$

Penggunaan breket pada perawatan ortodonti bertujuan untuk menghasilkan pergerakan gigi yang diinginkan. Lebar slot breket sangat penting untuk menghasilkan dayauntuk pergerakan gigi secara tiga dimensi.Daya ini dihasilkan dari penempatan kawat yang tepat ke dalam slot breket sehingga kawat dan breket ortodonti dapat berinteraksi.Lebar slot breket yang tidak sesuai, tidak menghasilkan pergerakan gigi yang diinginkan. ${ }^{3}$

Kusy dan Whitley ${ }^{4}$ pada penelitiannya mengenai 24 jenis breket, menyimpulkan bahwa tiga jenis breket memiliki ukuran slot breket yang lebih kecil dari standardan 20 jenis breket memiliki ukuran slot breket yang lebih besar dari pada standar ukuran pabrik produsen breket tersebut. Slot breket ukuran 0,018 inci yang diteliti, memiliki ukuran terbesar 0,02088 inci ( $16 \%$ lebih besar dari standar) dan pada slot breket 0,022 inci terdapat ukuran terbesar 0,02376 inci ( $8 \%$ lebih besar dari standar). Sedangkan Cash $\mathrm{dkk}^{3}$ menunjukkan bahwa 11 jenis breket dari 6 produsen yang berbeda menunjukkan ukuran slot breket yang lebih besar daripada standar yang dikeluarkan oleh pabrik produsen breket ortodonti tersebut.

Produsen breket ortodonti di negara-negara Eropa yang menggunakan satuan ukur yang berbeda dengan Amerika Serikat juga menghasilkan ukuran slot breket lebih besar 4,22\% dari ukuran slot breket 0,022 inci akibat perbedaan satuan ukur tersebut. ${ }^{4,5}$

Pengalaman klinik peneliti selama melakukan perawatan ortodonti di klinik Spesialis Ortodonti Fakultas Kedokteran Gigi Universitas Padjadjaran, 
menemukan keganjilan dalam ukuran slot breket. Kadang-kadang slot breket sulit untuk dimasukkan atau tidak berkontak dengan busur kawat. Hal ini menyebabkan busur kawat tersebut tidak berfungsi sehingga pergerakan gigitidak sesuai dengan rencana perawatan.Di Indonesia,belum ada badan pengawas mutu dari produk breket yang dipasarkan, sehingga mungkin ukuran slot breket tidak tidakakurat.

Tujuan penelitian ini adalah untuk mengetahui apakah ukuran slot breket ortodonti yang dipasarkan di Indonesia sesuai dengan standar yang ditetapkan $(0,018$ inci) sehingga ada gambaran keakuratan ukuran slot breket ortodonti yang tersedia.

\section{BAHAN DAN METODE}

Breket ortodonti yang diteliti berjumlah 1520 breket dengan ukuran slot 0,018 inci dari 9 produk breket yang beredar di Indonesia, dengan alat ukur yang disebut profil proyektor (Mitutoyo, PJ250). Pemilihan breket dilakukan secara acak dari 3 area produsen, yaitu Eropa, Amerika dan Asia, sehingga didapati beberapa merek dan jenis breket ortodonti. Breket yang berasal darimerekyang sama, dibedakan berdasarkan jenis breket tersebut, sehingga terdapat 20 buah breket pada setiap jenis breket.

Penelitian ini dilakukan pada 15 tipe breket, yaitu M1 (Forestadent) Mini Mono bracket (Standard Edgewise System) dan Mini Mono Bracket (Roth System S2); M2 (Dentaurum) Ultratrim (Standard Edgewise System), Ultra Minitrim (Roth System) dan Equilibrium Mini (Roth System); M3 (OrthoCorrect) Mini Edgewise System dan Mini Roth System; M4 (Dentsply Sarkin) Pre Torque Twin (Roth System); M5 (Ortho Source) Mini Cast (Roth System); M6(Ormco)Mini 2000 (Standard Edgewise System) dan Mini 2000 (Roth System); M7 (Ortho Organizer) Opti-MIM (Standard Edgewise System) dan Elite Opti-MIM (Roth System) dan M8 (RMO) Integra Bracket Kit (StandardEdgewise System) dan Integra Bracket Kit (Roth Straight Wire System).

\section{Cara penelitian}

Breket yang diteliti dikelompokkan berdasarkan produsen pembuatnya. Setelah itu breket dibedakan berdasarkan ukuran standar dari slot breket 0,018. Selanjutnya, breket dibedakan menurut jenisnya. Ukuran slot breket ditentukan dengan meletakkan breket di dalamprofil proyektor; breket akan dilewati oleh sinar yang akan diproyeksikan ke monitor dan diukur secara otomatis.

Pengukuran dilakukanatas 4 sisi dari tiap breket, dan untuk masing-masing merek,tipe dan sisi diukur atas 20 sampel breket. Gambar 1 menunjukkan cara pengukuran breket tersebut. Untuk mengurangi tingkat kejenuhan pada saat melakukan pengukuran yang dapat mengakibatkan kesalahan, maka pengukuran hanya dilakukan pada 1 tipe breket per hari.

Data hasil pengukuran slot breket dianalisis menggunakan uji-t satu pihak.

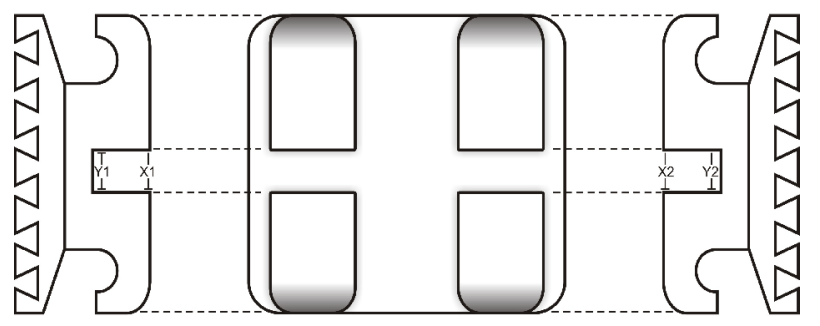

Gambar 1 Sisi slot breket yang diukur; X1: jarak vertikal slot breket sisi terluar diukur dari mesial; Y1: jarak vertikal slot breket sisi terdalam diukur dari mesial; X2: jarak vertikal slot breket sisi terluar diukur dari distal; Y2: jarak vertikal slot breket sisi terdalam diukur dari distal.

\section{HASIL \\ Pengukuran merek m1}

Hasil pengukuran pada 4 sisi slot breket $\mathrm{ml}$ tipe 1 dan 2 menunjukkan bahwa seluruh rata-rata lebar slot breket tidak sesuai dengan standar 0,018 inci. Bedanya,jarak vertikal sisi terluar dan terdalam slot breket ortodonti tipe 2, baik pada mesial dan distalnya, menunjukkan hasil yang sama $(0,0207$ inci), juga tidak sesuai dengan standar.

Berdasarkan data pada tabel 1 tampak perbedaan antara ukuran slot breket 0,018 inci dengan hasil pengukuran yang pada slot breket $\mathrm{m} 1$. Dengan uji-t diketahui perbedaan ukuran slot breket $\mathrm{m} 1$ secara bermakna dibandingkan dengan standar.

Tabel 1 Uji statistik rata-rata ukuran slot breket ortodonti m1 tipe 1 dan tipe 2 ukuran 0,018 inci

\begin{tabular}{|c|c|c|c|c|c|c|}
\hline Merek/Tipe & SP & $\bar{x}$ & Std & t Hit & t Tab & \% Perubahan \\
\hline \multirow{4}{*}{$\mathrm{m} 1 / \mathrm{t} 1$} & $\mathrm{X} 1$ & 0,0210 & 0,0021 & 6,47 & 1,725 & $16,69^{*}$ \\
\hline & $\mathrm{X} 2$ & 0,0210 & 0,0021 & 6,38 & 1,725 & $16,74 *$ \\
\hline & Y1 & 0,0208 & 0,0019 & 6,61 & 1,725 & $15,66^{*}$ \\
\hline & Y2 & 0,0208 & 0,0020 & 6,31 & 1,725 & $15,51 *$ \\
\hline \multirow{4}{*}{$\mathrm{m} 1 / \mathrm{t} 2$} & $\mathrm{X} 1$ & 0,0207 & 0,0022 & 5,52 & 1,725 & $15,20^{*}$ \\
\hline & $\mathrm{X} 2$ & 0,0207 & 0,0022 & 5,58 & 1,725 & $15,28 *$ \\
\hline & Y1 & 0,0207 & 0,0022 & 5,43 & 1,725 & $14,83^{*}$ \\
\hline & Y2 & 0,0207 & 0,0022 & 5,42 & 1,725 & $14,83 *$ \\
\hline
\end{tabular}




\section{Pengukuran merek m2}

Pengukuran slot breket $\mathrm{m} 2$ dilakukan pada 3 tipe breket (tabel 2), berdasarkan teknik perawatan, dan berukuran standar 0,018 inci. Pada tipe 1 tampak bahwa semua rerata lebar slot breket lebih besar dari standar,baik pada sisi dalam maupun sisi luar slot braket.

Pengukuran yang dilakukan pada 4 sisi slot breket merek $\mathrm{m} 2$ tipe 2 juga menunjukkan hal yang serupa dengan $\mathrm{m} 2 \mathrm{t} 1$. Hasil pengukuran jarak vertikal sisi terluar mesial dan distal slot breket menunjukkan hasil yang sama $(0,0224 \mathrm{inci})$.Sedangkan pengukuran jarak vertikal sisi terdalam mesial dan distal juga menunjukkan hasil serupa $(0,0223$ inci). Terdapat perbedaan pada sisi slot breket terluar dan terdalam, baik dari mesial maupun distal, sebesar 0,0001 inci.

Pengukuran pada 4 sisi slot breket ortodonti merek $\mathrm{m} 2$ tipe 3 menunjukkan bahwa seluruh ratarata lebar slot breket lebih besar dari standar 0,018 inci.Hasil pengukuran pada jarak vertikal sisi terluar mesial dan distal slot breket menunjukkan hasil sama (0,0217 inci). Sedangkan pengukuran jarak vertikal sisi terdalam pada mesial dan distal slot breket juga menunjukkan hasil sama $(0,0218$ inci). Terdapat perbedaan 0,0001 inci pada sisi slot breket terluar dan terdalam, baik mesial maupun distal. Dengan uji$\mathrm{t}$ diketahui perbedaan ukuran slot breket $\mathrm{m} 2$,secara bermakna dibandingkan dengan standar.

\section{Pengukuran merek m3}

Pengukuran slot breket merek m3 dilakukan pada 2 tipe breket $\mathrm{m} 3$ berdasarkan teknik perawatan dan berukuran standar 0,018 inci.Pada Tipe 1 didapatkan bahwa seluruh rata-rata lebar slot breket lebih besar dari standar 0,018 inci,yaitu jarak vertikal sisi terluar pada mesial dan distal slot breket 0,0191 inci. Sedangkan jarak vertikal sisi terdalam mesial dan distal slot breket juga menunjukkan hasil yang sama (0,0190 inci). Terdapat perbedaan pada sisi slot breket terluar dan terdalam,baik dari mesial maupun distal, sebesar 0,0001 inci.

Pengukuran yang dilakukan kepada 4 sisi slot breket merek $\mathrm{m} 3$ tipe 2 juga menunjukkan bahwa seluruh rata-rata lebar slot breket lebih besar dari standar. Hasil pengukuran pada jarak vertikal sisi terluar mesial dan distal slot breket menunjukkan hasil yang sama, sedangkan hasil pengukuran pada jarak vertikal sisi terdalam pada mesial dan distal slot breket juga menunjukkan hasil yang sama (0,0205 inci). Terdapat perbedaan pada sisi slot breket terluar dan terdalam,baik dari mesial maupun distal, sebesar 0,0002 inci. Dengan uji-t diketahui perbedaan ukuran slot breket $\mathrm{m} 3$ secara bermakna dibandingkan dengan standar (tabel 3).

Tabel 2 Uji statistik rata-rata ukuran slot breket ortodonti merek m2 (standar 0,018 inci)

\begin{tabular}{ccccccc}
\hline Merek/Tipe & SP & $\bar{x}$ & Std & t Hit & t Tab & \% Perubahan \\
\hline \multirow{3}{*}{ m2/t1 } & X1 & 0,0214 & 0,0011 & 14,42 & 1,725 & $18,83^{*}$ \\
& X2 & 0,0214 & 0,0011 & 14,43 & 1,725 & $18,82^{*}$ \\
& Y1 & 0,0214 & 0,0010 & 14,70 & 1,725 & $19,05^{*}$ \\
& Y2 & 0,0214 & 0,0010 & 14,70 & 1,725 & $19,05^{*}$ \\
\hline \multirow{2}{*}{ m2/t2 } & X1 & 0,0224 & 0,0018 & 10,69 & 1,725 & $24,45^{*}$ \\
& X2 & 0,0224 & 0,0018 & 10,85 & 1,725 & $24,56^{*}$ \\
& Y1 & 0,0223 & 0,0017 & 11,68 & 1,725 & $24,08^{*}$ \\
& Y2 & 0,0223 & 0,0017 & 11,68 & 1,725 & $24,08^{*}$ \\
\hline \multirow{2}{*}{ m2/t3 } & X1 & 0,0217 & 0,0013 & 12,49 & 1,725 & $20,76^{*}$ \\
& X2 & 0,0217 & 0,0013 & 12,48 & 1,725 & $20,77^{*}$ \\
& Y1 & 0,0218 & 0,0013 & 12,66 & 1,725 & $20,86^{*}$ \\
SP: sisi pengukuran & $\bar{r}$ & : rata-rata & Std: standar deviasi & tHit: tHitung & tTab: tTabel & $*$ : signifikan
\end{tabular}

Tabel 3 Uji statistik rata-rata ukuran slot breket ortodonti merek m3 (inci)

\begin{tabular}{ccccccc}
\hline Merek/tipe & SP & $\bar{x}$ & Std & t Hit & t Tab & \% Perubahan \\
\hline \multirow{4}{*}{$\mathrm{m} 3 / \mathrm{t} 1$} & $\mathrm{X} 1$ & 0,0191 & 0,0016 & 3,13 & 1,725 & $6,09^{*}$ \\
& $\mathrm{X} 2$ & 0,0191 & 0,0016 & 3,13 & 1,725 & $6,09^{*}$ \\
& $\mathrm{Y} 1$ & 0,0190 & 0,0016 & 2,78 & 1,725 & $5,54^{*}$ \\
& $\mathrm{Y} 2$ & 0,0190 & 0,0016 & 2,78 & 1,725 & $5,54^{*}$ \\
\hline \multirow{3}{*}{$\mathrm{m} 3 / \mathrm{t} 2$} & $\mathrm{X} 1$ & 0,0203 & 0,0018 & 5,58 & 1,725 & $12,55^{*}$ \\
& $\mathrm{X} 2$ & 0,0203 & 0,0018 & 5,58 & 1,725 & $12,55^{*}$ \\
& $\mathrm{Y} 1$ & 0,0205 & 0,0017 & 6,65 & 1,725 & $14,07^{*}$ \\
& $\mathrm{Y} 2$ & 0,0205 & 0,0017 & 6,65 & 1,725 & $14,07^{*}$ \\
\hline
\end{tabular}

SP: sisi pengukuran $\bar{x}$ : rata-rata Std: standar deviasi tHit: tHitung tTab: tTabel *: signifikan 


\section{Pengukuran merek m4}

Pengukuran slot breket merek m4 mendapatkan seluruh rata-rata lebar slot breket lebih besar dari standar 0,018 inci. Hasil pengukuran pada jarak vertikal sisi terluar mesial menunjukkan 0,0194 inci, sedangkan sisi distal slot breket menunjukkan 0,0197 inci. Hasil pengukuran pada dimensi vertikal sisi terdalam pada mesial dan distal slot breket menunjukkan hasil yang sama, yaitu 0,0196 inci. Dengan uji-t diketahui perbedaan ukuran slot breket $\mathrm{m} 4$ secara bermakna dibandingkan dengan standar (tabel 4).

\section{Pengukuran merek m5}

Pengukuran slot breket merek m5 mendapatkan bahwa seluruh rata-rata lebar slot breket lebih besar dari standar 0,018 inci. Pengukuran dimensi jarak vertikal sisi terluar pada mesial menunjukkan hasil 0,0198 inci;sedangkan dimensi sisi distal slot breket menunjukkan hasil 0,0197 inci. Hasil pengukuran pada jarak vertikal sisi terdalam pada mesial dan distal slot breket menunjukkan 0,0191 inci Dengan uji-t diketahui perbedaan ukuran slotbreketm5 secara bermakna dibandingkan dengan standar (tabel 5).

\section{Pengukuran merek m6}

Pengukuran slot breket pada merek m6 dilakukan berdasarkan teknik perawatan pada 2 tipe breket dan berukuran standar 0,018 inci. Pada tipe 1 didapatkan seluruh rata-rata lebar slot breket lebih besar dari standar. Hasil pengukuran dimensi jarak vertikal sisi terluar pada mesial menunjukkan hasil rata-rata sebesar 0,0216 inci dan pada sisi distal slot breket menunjukkan hasil 0,0218 inci. Hasil pengukuran dimensi jarak vertikal sisi terdalam pada mesial menunjukkan hasil 0,0198 inci dan sisi distal slot breket menunjukkan 0,200 inci. Pengukuran yang dilakukan kepada 4 sisi slot breket merek m6 tipe 2 juga menunjukkan seluruh rata-rata lebar slot breket tidak sesuai dengan standar. Hasil pengukuran pada jarak vertikal sisi terluar pada mesial dan distal slot breket menunjukkan hasil yang sama. Pengukuran jarak vertikal sisi terdalam slot breket ortodonti, baik pada sisi mesial sebesar 0,0196 inci dan sisi distal slot breket menunjukkan hasil 0,0198 inci. Dengan uji-t diketahui perbedaan ukuran slot breket m6 secara bermakna dibandingkan dengan standar (tabel 6).

\section{Pengukuran merek m7}

Pengukuran ke 4 sisi slot breket ortodonti merek $\mathrm{m} 7$ berdasarkan teknik perawatan pada 2 tipe breket dan berukuran standar 0,018 inci. Pada Tipe 1 didapatkan seluruh rata-rata lebar slot breket lebih besar dari standar 0,018 inci.Hasil pengukuran ratarata pada jarak vertikal sisi terluar pada sisi mesial

Tabel 4 Uji statistik rata-rata ukuran slot breket ortodonti merek m4 (0,018 inci)

\begin{tabular}{ccccccc}
\hline Merek & SP & $\bar{x}$ & Std & t Hit & t Tab & \%Perubahan \\
\hline \multirow{3}{*}{ m4 } & X1 & 0,0194 & 0,0017 & 3,71 & 1,725 & $7,90^{*}$ \\
& X2 & 0,0197 & 0,0017 & 4,32 & 1,725 & $9,23^{*}$ \\
& Y1 & 0,0196 & 0,0013 & 5,36 & 1,725 & $8,76^{*}$ \\
& Y2 & 0,0196 & 0,0013 & 5,56 & 1,725 & $9,02^{*}$ \\
\hline
\end{tabular}

SP: sisi pengukuran $\bar{x}$ : rata-rata Std: standar deviasi tHit: tHitung tTab: tTabel *: signifikan

Tabel 5 Uji statistik rata-rata ukuran slot breket ortodonti merek m5 (0,018 inci)

\begin{tabular}{ccccccc}
\hline Merek & SP & $\bar{x}$ & Std & t Hit & t Tab & \%Perubahan \\
\hline \multirow{3}{*}{ m5 } & X1 & 0,0198 & 0,0015 & 5,41 & 1,725 & $9,82^{*}$ \\
& X2 & 0,0197 & 0,0014 & 5,18 & 1,725 & $9,20^{*}$ \\
& Y1 & 0,0191 & 0,0016 & 3,09 & 1,725 & $5,95^{*}$ \\
& Y2 & 0,0191 & 0,0016 & 3,16 & 1,725 & $6,18^{*}$ \\
\hline
\end{tabular}

SP: sisi pengukuran $\bar{x}$ : rata-rata Std: standar deviasi tHit: tHitung tTab: tTabel *: Signifikan

Tabel 6 Uji statistik rata-rata ukuran slot breket ortodonti merek m6 $(0,018$ inci)

\begin{tabular}{ccccccc}
\hline Merek/tipe & SP & $\bar{x}$ & Std & t Hit & t Tab & \% Perubahan \\
\hline \multirow{3}{*}{ m6/t1 } & X1 & 0,0216 & 0,0015 & 10,56 & 1,725 & $19,96^{*}$ \\
& X2 & 0,0218 & 0,0014 & 12,36 & 1,725 & $20,92^{*}$ \\
& Y1 & 0,0198 & 0,0012 & 6,44 & 1,725 & $9,78^{*}$ \\
& Y2 & 0,0200 & 0,0013 & 7,16 & 1,725 & $11,32^{*}$ \\
\hline \multirow{3}{*}{ M6/t2 } & X1 & 0,0207 & 0,0008 & 15,71 & 1,725 & $14,76^{*}$ \\
& X2 & 0,0207 & 0,0011 & 11,33 & 1,725 & $15,28^{*}$ \\
& Y1 & 0,0196 & 0,0014 & 5,28 & 1,725 & $9,03^{*}$ \\
SP: sisi pengukuran & Y2 & 0,0198 & 0,0011 & 7,00 & 1,725 & $9,91^{*}$ \\
& $\bar{x}$ : rata-rata & Std: standar deviasi & tHit: tHitung & tTab: tTabel *: Signifikan
\end{tabular}


Tabel 7 Uji statistik rata-rata ukuran slot breket ortodonti merek $\mathrm{m} 7(0,018$ inci)

\begin{tabular}{ccccccc}
\hline Merek & SP & $\bar{x}$ & Std & t Hit & t Tab & \% Perubahan \\
\hline \multirow{3}{*}{$\mathrm{m} 7 / \mathrm{t} 1$} & $\mathrm{X} 1$ & 0,0209 & 0,0014 & 9,13 & 1,725 & $16,20^{*}$ \\
& $\mathrm{X} 2$ & 0,0205 & 0,0012 & 9,52 & 1,725 & $13,98^{*}$ \\
& $\mathrm{Y} 1$ & 0,0200 & 0,0017 & 5,49 & 1,725 & $11,38^{*}$ \\
& $\mathrm{Y} 2$ & 0,0196 & 0,0012 & 5,87 & 1,725 & $9,00^{*}$ \\
\hline \multirow{3}{*}{$\mathrm{m} 7 / \mathrm{t} 2$} & $\mathrm{X} 1$ & 0,0208 & 0,0017 & 7,25 & 1,725 & $15,38^{*}$ \\
& $\mathrm{X} 2$ & 0,0206 & 0,0009 & 12,85 & 1,725 & $14,34^{*}$ \\
& $\mathrm{Y} 1$ & 0,0200 & 0,0015 & 5,98 & 1,725 & $11,37^{*}$ \\
\hline SP: sisi pengukuran & $\bar{x}:$ rata-rata & Std: standar deviasi & tHit: tHitung & tTab: tTabel & *: Signifikan
\end{tabular}

Tabel 8 Uji statistik rata-rata ukuran slot breket ortodonti merek m8

\begin{tabular}{ccccccc}
\hline Merek/tipe & SP & $\bar{x}$ & Std & t Hit & t Tab & \% Perubahan \\
\hline \multirow{3}{*}{$\mathrm{m} 8 / \mathrm{t} 1$} & $\mathrm{X} 1$ & 0,0210 & 0,0021 & 6,47 & 1,725 & $16,69^{*}$ \\
& $\mathrm{X} 2$ & 0,0210 & 0,0021 & 6,38 & 1,725 & $16,74^{*}$ \\
& $\mathrm{Y} 1$ & 0,0195 & 0,0010 & 6,63 & 1,725 & $8,18^{*}$ \\
& Y2 & 0,0194 & 0,0008 & 7,72 & 1,725 & $7,60^{*}$ \\
\hline \multirow{3}{*}{$\mathrm{m} 8 / \mathrm{t} 2$} & $\mathrm{X} 1$ & 0,0195 & 0,0013 & 5,15 & 1,725 & $8,06^{*}$ \\
& $\mathrm{X} 2$ & 0,0197 & 0,0010 & 7,53 & 1,725 & $9,70^{*}$ \\
& $\mathrm{Y} 1$ & 0,0194 & 0,0012 & 5,09 & 1,725 & $7,87^{*}$ \\
& $\mathrm{Y} 2$ & 0,0198 & 0,0009 & 9,22 & 1,725 & $10,16^{*}$ \\
\hline
\end{tabular}

SP: sisi pengukuran $\bar{x}$ : rata-rata Std: standar deviasi tHit: tHitung tTab: tTabel *: Signifikan

menunjukkan 0,0209 inci dan pada sisi distal slot breket menunjukkan rata-rata sebesar 0,0205 inci. Pengukuran pada jarak vertikal sisi terdalam pada sisi mesial menunjukkan hasil rata-rata sebesar 0,0200 inci dan pada sisi distal slot breket menunjukkan hasil rata-rata sebesar 0,0196 inci. Pada tipe 2 juga menunjukkan rata-rata lebar slot breket tidak sesuai dengan standar 0,018 inci. Hasil pengukuran ratarata pada jarak vertikal sisi terluar pada sisi mesial menunjukkan hasil 0,0208 inci dan pada sisi distal slot breket menunjukkan rata-rata sebesar 0,0206 inci. Hasil pengukuran jarak vertikal sisi terdalam pada sisi mesial menunjukkan hasil rata-rata sebesar 0,0200 inci dan pada sisi distal menunjukkan hasil rata-rata sebesar 0,0196 inci. Dengan uji-t diketahui perbedaan ukuran slot breket $\mathrm{m} 7$ secara bermakna dibandingkan dengan standar (tabel 7).

\section{Pengukuran merek m8}

Pengukuran dimensi pada slot breket merek $\mathrm{m} 8$ dilakukan berdasarkan teknik perawatan pada 2 tipe breket yang berukuran standar 0,018 inci. Pada tipe 1 didapatkan bahwa seluruh rata-rata lebar slot breket lebih besar dari 0,018 inci. Hasil pengukuran pada jarak vertikal sisi terluar pada mesial dan distal slot breket menunjukkan hasil yang sama (0,0210 inci) sedangkan hasil pengukuran pada jarak vertikal sisi terdalam pada sisi mesial menunjukkan hasil ratarata sebesar 0,0195 inci dan pada sisi distal slot breket menunjukkan hasil rata-rata sebesar 0,0194 (tabel 15). Pengukuran tipe 2 juga menunjukkan bahwa seluruh rata-rata lebar slot breket tidak sesuai dengan standar. Hasil pengukuran rata-rata padajarak vertikal sisi terluar pada sisi mesial menunjukkan hasil 0,0195 inci dan pada sisi distal slot breket menunjukkan hasil rata-rata sebesar 0,0197 inci. Hasil pengukuran pada jarak vertikal sisi terdalam pada sisi mesial menunjukkan hasil rata-rata sebesar 0,0194 inci dan sisi distal slot breket menunjukkan hasil rata-rata sebesar 0,0198 inci. Dengan uji-t diketahui perbedaan ukuran slot breket $\mathrm{m} 8$ secara bermakna dibandingkan dengan standar (tabel 8).

\section{Hasil pengukuran slot breket 0,018 inci}

Hasil pengukuran dimensi kelompok slot breket 0,018 inci memperlihatkan rata-rata pembesaran slot terhadap ukuran standar melebihi 5\% (tabel 9).

Tabel 9 Persentase pembesaran ukuran slot breket dibandingkan standar 0,018 inci

\begin{tabular}{ccc}
\hline Merek & Tipe & \% Pembesaran Ukuran \\
\hline \multirow{2}{*}{$\mathrm{m} 1$} & 1 & $16,15 \%$ \\
& 2 & $15,04 \%$ \\
$\mathrm{~m} 2$ & 1 & $18,94 \%$ \\
& 2 & $24,29 \%$ \\
$\mathrm{~m} 3$ & 3 & $20,81 \%$ \\
$\mathrm{~m} 4$ & 1 & $5,81 \%$ \\
$\mathrm{~m} 5$ & 1 & $13,31 \%$ \\
$\mathrm{~m} 6$ & 1 & $8,73 \%$ \\
& 1 & $8,79 \%$ \\
$\mathrm{~m} 7$ & 1 & $15,49 \%$ \\
& 2 & $12,25 \%$ \\
$\mathrm{~m} 8$ & 1 & $12,64 \%$ \\
& 2 & $12,44 \%$ \\
\hline
\end{tabular}


Rata-rata persentase pembesaran ukuran terkecil pada merek m3 tipe 1 sebesar $5,18 \%$ dan terbesar pada merek $\mathrm{m} 2$ tipe 2 sebesar $24,29 \%$.

Berdasarkan hasil pengukuran,breket ortodonti yang dipasarkan di Indonesia memiliki ukuran slot lebih besar dari ukuran standar. Pengujian secara statistik membuktikan bahwa ukuran lebar slot breket ortodonti, yang dipasarkan di Indonesia, memiliki ukuran yang tidak sesuai dengan ukuran standar.

\section{PEMBAHASAN}

Cash $\mathrm{dkk}^{3}$ melakukan penelitian evaluasi ukuran slot breket komersil yang dikeluarkan oleh pabrik. Hasil penelitian menunjukkan bahwa dari 10 jenis breket dari 6 jenis breket ukuran slot breket lebih besar daripada ukuran standar (tabel 10). Penelitian tersebut dilakukan pada breket untuk gigi insisivus sentralis dengan menggunakan alat Maxtascan 100.

Siatkowsky ${ }^{6}$ juga menyatakan ukuran slot breket ortodonti produksi negara-negara di Eropa yang menggunakan ukuran metrik berbeda dengan ukuran slot breket buatan Amerika yang menggunakan sistem pengukuran imperial. Hal ini menyebabkan ukuran slot breket ortodonti 0,022 inci menjadi lebih besar 4,22\% pada ukuran slot breket buatan negara-negara Eropa.

Pada sebuah penelitian lain,Kusy dan Whitley ${ }^{4}$ melakukan penelitian pada 24 breket dari 8 pabrik, menyatakan bahwa tiga jenis breket lebih kecil dan 20 jenis slot breket lebih besar daripada ukuran standar.Tabel 11 menunjukkan hasil pengukuran slot breket oleh Kusy dan Whitley. Ukuran slot breket ortodonti dapat menyebabkan pergerakan gigi yang tidak diharapkan, karena hubungan antara breket

Tabel 10 Hasil pengukuran slot breket Cash, dkk. ${ }^{3}$

\begin{tabular}{lcc}
\hline \multicolumn{1}{c}{ Nama merek breket/tipe } & Ukuran Standar dari Produsen (inci) & Hasil Penelitian (inci) \\
\hline Twin Torque Roth & 0,018 & 0,0189 \\
Clarity MBT & 0,018 & 0,0189 \\
Victory Series MBT & 0,018 & 0,01908 \\
Elegance Plastic Roth & 0,018 & 0,02016 \\
Mini Mono MBT & 0,018 & 0,0189 \\
Nu-Edge Roth & 0,018 & 0,02052 \\
Mxi Advant-Edge Roth & 0,018 & 0,02106 \\
Damon II SL Roth & 0,018 & 0,02106 \\
Elite Mini Opti-MIM Roth & 0,018 & 0,02106 \\
Elite Mini Opti-MIM MBT & 0,018 & 0,02106 \\
\hline
\end{tabular}

Tabel 11 Hasil pengukuran slot breket Kusy \& Whitley ${ }^{4}$

\begin{tabular}{|c|c|c|c|}
\hline Perusahaan & Breket & Ukuran Slot $\left(10^{-3}\right.$ inci $)$ & Hasil Pengukuran $\left(10^{-3}\right.$ inci $)$ \\
\hline \multirow{2}{*}{$\begin{array}{c}\text { "A" Company } \\
\text { (San Diego, Calif.) }\end{array}$} & Starfire & 18 & $18,2 \pm 0,2$ \\
\hline & Starfire & 22 & $22,4 \pm 0,2$ \\
\hline \multirow{11}{*}{$\begin{array}{l}\text { American Orthod. } \\
\text { (Sheboygan, Wisc.) }\end{array}$} & $20 / 20$ & 18 & $17,8 \pm 0,2$ \\
\hline & $20 / 20$ & 22 & $21,5 \pm 0,1$ \\
\hline & Fascination & 18 & $20,7 \pm 0,5$ \\
\hline & Fascination & 22 & $23,6 \pm 0,5$ \\
\hline & Rematitan $\left(7^{\circ} \mathrm{T}\right)$ & 18 & $20,9 \pm 0,3$ \\
\hline & Rematitan $\left(17^{0} \mathrm{~T}\right)$ & 18 & $20,1 \pm 0,3$ \\
\hline & Ultra-minitrim & 18 & $20,4 \pm 0,2$ \\
\hline & Ultra-minitrim & 18,5 & $19,5 \pm 0,1$ \\
\hline & Ultra-minitrim $\left(7^{\circ} \mathrm{T}\right)$ & 18,5 & $18,6 \pm 0,2$ \\
\hline & Ultra-minitrim $\left(17^{0} \mathrm{~T}\right)$ & 18,5 & $19,9 \pm 0,1$ \\
\hline & Ultra-minitrim & 22 & $23,7 \pm 0,2$ \\
\hline GAC (New York) & Allure III & 22 & $22,8 \pm 0,1$ \\
\hline \multirow{2}{*}{$\begin{array}{l}\text { Ormco/Sybron } \\
\text { (Glendora, Calif.) }\end{array}$} & Lumina Twin & 18 & $18,3 \pm 0,5$ \\
\hline & Lumina Twin & 22 & $22,3 \pm 0,1$ \\
\hline \multirow{2}{*}{$\begin{array}{c}\text { RMO } \\
\text { (Denver, Colo.) }\end{array}$} & Quasar & 18 & $18,1 \pm 0,2$ \\
\hline & Quasar & 22 & $21,9 \pm 0,1$ \\
\hline \multirow[t]{2}{*}{ TP Orthod. } & Advant-edge & 22 & $22,8 \pm 1,1$ \\
\hline & Mini Uni. Twin & 22 & $23,2 \pm 0,0$ \\
\hline \multirow{4}{*}{$\begin{array}{c}\text { Unitek/3M } \\
\text { (Monrovia, Calif.) }\end{array}$} & New Ceramic & 18 & $18,0 \pm 0,5$ \\
\hline & Transcend 6000 & 18 & $18,3 \pm 0,5$ \\
\hline & Transcend 6000 & 22 & $22,6 \pm 0,1$ \\
\hline & Victory Mini Twin & 18 & $18,3 \pm 0,2$ \\
\hline
\end{tabular}


ortodonti dan archwire tidak optimal. ${ }^{3}$ Perbedaan yang signifikan menunjukkan pentingnya dokter gigi praktisi ortodonti untuk kritis dalam memilih merek breket dan jenisnya, serta memikirkan cara untuk mengatasi dampak dari kurang akuratnya ukuran slot breket. Pengalaman klinis selama melakukan perawatan ortodonti merujuk pada seringnya terjadi kesulitan untuk mengontrol pergerakan gigi.

Pada bidang ortodonti, ketepatan ukuran slot breket sangat penting untuk keberhasilan perawatan. Penempatan kawat pada slot breket ortodonti secara tepat akan menghasilkan gaya untuk pergerakan gigi secara tiga dimensi. Gaya tersebut dihasilkan dari kesesuaian ukuran kawat dengan ukuran slot breket. Hubungan antara kawat dan slot breket yang terlalu ketat atau longgar menyebabkan transmisi gaya yang tidak sempurna pada gigi. ${ }^{6-10}$

Berdasarkan penjelasan yang telah diuraikan sebelumnya, keakuratan ukuran slot breket penting untuk menghasilkan pergerakan gigi yang optimal dalam perawatan ortodonti. Sedangkan berdasarkan hasil penelitian Cash, $\mathrm{dkk}^{3}$, dan Kusy \& Whitley ${ }^{4}$ ditunjukkan bahwa ukuran slot yang dipasarkan tidak sesuai dengan standarnya. Hasil penelitian ini juga menunjukkan perbedaan ukuran slot breket.

Dari penelitian ini, disimpulkan bahwa ada perbedaan ukuran slot breket ortodonti 0,018 inci yang beredar di Indonesia, karena memiliki ukuran lebih besar antara 5,18-24,29\% dari ukuran slot breket standar 0,018 inci.

\section{DAFTAR PUSTAKA}

1. Graber TM, Vanarsdall RL. Orthodontics: current principles and techniques. $2^{\text {nd }}$ Ed. St Louis: Mosby Year Book Inc.; 1994. p.62-3.

2. Proffit WR, Fields HW. Contemporary orthodontics. $3^{\text {rd }}$ Ed. St Louis: Mosby Inc.; 2000. p.15-8, 385-416.

3. Cash AC, Good SA, Curtis RV. An evaluation of slot size in orthodontic brackets - are standards as expected? Angle Orthodont 2004; 74 (4): 450-3.

4. Kusy R, Whitey J. Assessment of second-order clearences between orthodontics archwire and bracket slots via the critical contact angle for binding. Angle Orthodont 1999; 69(1): 71-80.

5. Peck S. Orthodontic slot size: it's time to retool. Angle Orthodont 2001; 71(5): 329-30.

6. Siatkowski R. Loss of anterior torque control due to variations in bracket slot and archwire dimensions. J Clin Orthod 1999; 33: 508-10.

7. Bennet JC, McLaughlin RP. Orthodontic treatment mechanics and the preadjusted appliance. San Diego: Wolfe Publishing; 1993.

8. Kang BS, Baek SH, Mah J. Three dimensional relationship between the critical angle and the torque angle. Am J Orthod Dentofac Orthop 2003; 123: 64-73.

9. Nanda R. 2004. Biomechanics and esthetic strategies in clinical orthodontics. St. Louis: Elsevier Inc.; 2004.

10. William JK. Fixed orthodontic appliances. Oxford: Wright an imprint of Butterwood-Heinemann; 1995. 